ACTA UNIVERSITATIS NICOLAI COPER NICI

DOI: http://dx.doi.org/10.12775/AUNC_ECON.2014.014 EKONOMIA XLV nr 2 (2014) 219-234

Pierwsza wersja złożona 13 lipca 2014

ISSN

Końcowa wersja zaakceptowana 20 grudnia 2014

2080-0339

Edyta Łaszkiewicz*

\title{
SKUTKI BŁĘDNEJ SPECYFIKACJI EFEKTÓW PRZESTRZENNYCH W BAYESOWSKIM MODELU AUTOREGRESJI PRZESTRZENNEJ. WYNIKI SYMULACJI MONTE CARLO**
}

$\mathrm{Z}$ a r y s t r e ś c i. Celem artykułu jest identyfikacja skutków pominięcia dodatkowych charakterystyk procesu przestrzennego w modelu SAR. W badaniu skupiono się na dwóch procesach przestrzennych - cechujących się występowaniem skorelowanych przestrzennie i niezależnych efektów losowych. Wyniki symulacji Monte Carlo wykazały m.in., iż pominięcie efektów losowych w modelu SAR skutkuje przeszacowaniem parametru interakcji przestrzennych oraz wariancji składnika losowego.

S łow a kluczowe: model przestrzennej autoregresji, efekty przestrzenne, MCMC, symulacja Monte Carlo.

K 1 a s y f i k a j a J E L: C11, C21, C63.

\section{WSTĘP}

Jednym z podstawowych modeli ekonometrii przestrzennej jest przestrzenny model autoregresji (SAR), będący rozszerzeniem tradycyjnego modelu regresji liniowej o opóźnienie przestrzenne zmiennej objaśnianej (por. Szulc, 2007; Suchecki, 2010). Mimo iż pozwala on analizować procesy odznaczające się autoregresją przestrzenną, nie pozwala ustosunkować się do

\footnotetext{
*Adres do korespondencji: Edyta Łaszkiewicz, Uniwersytet Łódzki, Katedra Ekonometrii Przestrzennej, ul. Rewolucji 1905 r. 37, 90-214 Łódź, e-mail: elaszkiewicz@uni.lodz.pl.

** Praca współfinansowana $\mathrm{z}$ grantu Narodowego Centrum Nauki numer UMO2013/08/T/HS4/00512.

(C) 2014 Uniwersytet Mikołaja Kopernika. All rights reserved. http://www.aunc.ekonomia.umk.pl
} 
ewentualnego występowania przestrzennej heterogeniczności procesu, jak również nie zezwala na występowanie bardziej złożonych, wielowymiarowych struktur zależności. Mając na względzie to, że zjawiska ekonomiczne i społeczne mogą cechować się skomplikowaną strukturą relacji w przestrzeni, jak również mając na uwadze popularność modelu SAR, istotne wydaje się zidentyfikowanie efektów niewłaściwej specyfikacji ww. modelu. W szczególności ważne, z punktu widzenia interpretacji efektów przestrzennych, będą skutki błędnego scharakteryzowania procesu przestrzennego, w postaci błędu estymatora parametru interakcji przestrzennych.

Spośród prac empirycznych podejmujących ww. zagadnienia wskazać można przede wszystkim te, które poświęcono skutkom pominięcia dodatkowej niejednorodności zjawiska $\mathrm{w}$ modelach wielopoziomowych ${ }^{1}$ (por. Moerbeek, 2004; Van den Noortgate i in., 2005) oraz te, wskazujące konsekwencje pominięcia przestrzennej autoregresji procesu w tradycyjnych modelach regresji liniowej (por. Anselin, 1988; Anselin i Griffith, 1988). W przypadku modeli wielopoziomowych wiadomo, że zignorowanie dodatkowego „poziomu” (inaczej heterogeniczności) danych przekłada się na przeszacowanie wariancji składnika losowego oraz wariancji efektów losowych. Z uwagi na brak interakcji przestrzennych w tradycyjnych modelach wielopoziomowych, potencjalny wpływ pominięcia heterogeniczności procesu na oszacowania parametrów interakcji przestrzennych nie jest jednak znany.

Wśród prac poświęconych ekonometrycznym modelom przestrzennym wskazać można m.in. takie, które odnoszą się do problemu wpływu pominiętej zmiennej na wybór modelu przestrzennego (por. Lacombe i LeSage, 2013), czy też takie, które podejmują kwestie związane z wielkością błędu modelu przestrzennego wynikającego z niewłaściwej specyfikacji zależności przestrzennych w postaci macierzy wag (por. Liu i in., 2014). Na tym tle problematyka zawarta $\mathrm{w}$ niniejszej pracy wydaje się tematem rzadko podejmowanym w dyskusji.

Badanie ma na celu określenie skutków błędnej specyfikacji modelu SAR. W praktyce rzeczywisty charakter procesu generującego dane nie jest znany, a badacz dokonuje wyboru modelu w oparciu o kryteria prognostyczne lub stosując miary dobroci dopasowania modelu do danych. Mimo tego, jeśli wśród porównywanych modeli nie znajdzie się taki, który uwzględnia heterogeniczność procesu, istnieje szansa wyboru modelu SAR. Dotyczy to w szczególności tych sytuacji, kiedy mamy do czynienia z występowaniem zarówno autokorelacji, jak i heterogeniczności przestrzennej.

${ }^{1}$ Definicję modelu wielopoziomowego znaleźć można m.in. u Goldsteina (2011). 
Błędną specyfikację modelu zdefiniowano w niniejszej pracy jako sytuację, w której proces przestrzenny o złożonej strukturze efektów przestrzennych jest traktowany przez badacza jako proces cechujący się wyłącznie autoregresją przestrzenną. W efekcie estymacja parametrów procesu odbywa się przy wykorzystaniu modelu SAR, który nie uwzględnia dodatkowych charakterystyk procesu.

W pracy zostały rozpatrzone dwa procesy przestrzenne, odznaczające się: 1) występowaniem przestrzennej heterogeniczności (w postaci niezależnych efektów losowych); 2) dodatkową strukturą zależności przestrzennych i heterogenicznością ( $w$ postaci skorelowanych przestrzennie efektów losowych). W celu określenia efektów niewłaściwej specyfikacji modelu SAR posłużono się wynikami symulacji Monte Carlo.

\section{BAYESOWSKA ESTYMACJA MODELU AUTOREGRESJI PRZESTRZENNEJ}

W modelu SAR zakłada się istnienie powiązań między wartościami procesu objaśnianego (w określonej przestrzeni), które uwzględniane są jako tzw. opóźnienie przestrzenne zmiennej zależnej. Model ma następującą postać ogólną (Anselin, 1988):

$$
\mathbf{Y}=\rho \mathbf{W Y}+\mathbf{X} \boldsymbol{\beta}+\boldsymbol{\varepsilon}, \quad \boldsymbol{\varepsilon} \sim \mathrm{N}\left(\mathbf{0}, \sigma_{\varepsilon}^{2} \mathbf{I}_{N}\right),
$$

gdzie:

$\mathbf{Y}$ - wektor $N \times 1$ objaśnianego procesu przestrzennego,

$\mathbf{X}$ - macierz $N \times K$ procesów objaśniających,

$\mathbf{W}$ - macierz $N \times N$ wag przestrzennych,

$\boldsymbol{\beta}$ - wektor $K \times 1$ parametrów strukturalnych,

$\rho$ - parametr interakcji przestrzennych,

$\boldsymbol{\varepsilon}$ - wektor $N \times 1$ składnika losowego,

$N$ - łączna liczba obserwacji w próbie.

Dla równania 1 estymator KMNK jest niezgodny (Lee, 2002). Pożądane własności estymatora można uzyskać, stosując metodę największej wiarygodności zmiennych instrumentalnych (por. Anselin, 1988), uogólnioną metodę momentów, czy też dwustopniową metodę najmniejszych kwadratów (por. Lee, 2007). Alternatywą dla powyższych jest zastosowanie podejścia bayesowskiego, rekomendowanego w przypadku estymacji bardziej zaawansowanych modeli przestrzennych (por. m.in. LeSage, 1997). Jedną z niewątpliwych zalet ww. podejścia jest możliwość uzyskania pełnego rozkładu a posteriori parametrów, co eliminuje konieczność asymptotycznych aproksymacji (wrażliwych np. w sytuacji dysponowania małymi próbami). Mając 
na względzie powyższe, w niniejszym badaniu dokonano estymacji bayesowskiej modelu SAR.

Punktem wyjścia estymacji bayesowskiej (por. Osiewalski, 2001) jest przyjęcie założenia, że rozkłady a posteriori parametrów $\mathbf{E}=\left\{\lambda, \rho, \sigma_{\varepsilon}{ }^{2}, \sigma_{\mu}{ }^{2}, \boldsymbol{\beta}\right\}$ odzwierciedlają zarówno wiedzę a priori badacza $P(\mathbf{E})$, jak i informacje „Z danych" Dane $=\{\mathbf{Y}, \mathbf{X}, \mathbf{W}\}$ wyrażone funkcją wiarygodności $P($ Dane $\mid \mathbf{E})$, co zapisać można następująco:

$$
P(\mathbf{E} \mid \text { Dane }) \propto P(\text { Dane } \mid \mathbf{E}) \times P(\mathbf{E}) .
$$

$\mathrm{Z}$ uwagi na brak oczekiwań co do wartości parametrów zastosowano słabo informacyjne rozkłady a priori parametrów $P(\mathbf{E})$ następującej postaci:

$$
\begin{aligned}
& P(\boldsymbol{\beta}) \sim \mathrm{N}\left(\mathbf{M}_{0}, \mathbf{T}_{0}\right), \quad P(\rho) \sim \mathrm{U}\left(1 / v_{\min }, 1\right), \\
& P\left(\sigma_{\varepsilon}^{2}\right) \sim \operatorname{IG}\left(c_{0}, d_{0}\right),
\end{aligned}
$$

gdzie:

$v_{\min }$ - najmniejsza wartość własna macierzy $\mathbf{W}$,

$c_{0}, d_{0}$ - parametr kształtu i skali odwrotnego rozkładu gamma,

$\mathbf{M}_{0}$ - wektor $K \times 1$ średnich wartości przestrzennych procesów objaśniających,

$\mathbf{T}_{0}$ - macierz $K \times K$ wariancji-kowariancji przestrzennych procesów objaśniających.

W celu wyznaczenia rozkładów a posteriori parametrów skorzystano z funkcji wiarygodności, która dla modelu SAR ma postać (LeSage i in., 2009, s. 47):

$$
\begin{aligned}
& L(\mathbf{Y} \mid \mathbf{E})=\left(2 \sigma_{\varepsilon}^{2}\right)^{-N / 2}\left|\mathbf{I}_{N}-\rho \mathbf{W}\right| \exp \left(-\frac{\mathbf{e} \mathbf{e}}{2 \sigma_{\varepsilon}^{2}}\right), \\
& \mathbf{e}=\mathbf{Y}-\rho \mathbf{W} \mathbf{Y}-\mathbf{X} \boldsymbol{\beta} .
\end{aligned}
$$

Wiedząc, że funkcję wiarygodności utożsamiamy z $P($ Dane $\mid \mathbf{E})$, rozkłady a posteriori poszczególnych parametrów wyznaczyć można następująco:

$$
P\left(\boldsymbol{\beta} \mid \mathbf{Y}, \rho, \sigma_{\varepsilon}^{2}\right) \sim \mathrm{N}\left(\mathbf{M}_{0}, \mathbf{T}_{0}\right),
$$

gdzie: $\mathbf{M}_{\beta}=\mathbf{T}_{\beta}\left[\frac{1}{\sigma_{\varepsilon}^{2}} \mathbf{X}^{\prime}(\mathbf{Y}-\rho \mathbf{W Y})+\mathbf{T}_{0}^{-1} \mathbf{M}_{0}\right], \quad \mathbf{T}_{\beta}=\left[\frac{1}{\sigma_{\varepsilon}^{2}} \mathbf{X}^{\prime} \mathbf{X}+\mathbf{T}_{0}^{-1}\right]^{-1}$.

$$
P\left(\sigma_{\varepsilon}^{2} \mid \mathbf{Y}, \boldsymbol{\beta}, \rho\right) \sim \operatorname{IG}\left(c_{e}, d_{e}\right),
$$

gdzie: $c_{e}=N / 2+c_{0}, \quad d_{e}=0,5 \times \mathbf{e} \mathbf{e}+d_{0}$. 


$$
P\left(\rho \mid \mathbf{Y}, \boldsymbol{\beta}, \sigma_{\varepsilon}^{2}\right) \propto\left|\mathbf{I}_{N}-\rho \mathbf{W}\right| \sigma_{\varepsilon}^{-(N+1)} \exp \left\{-\frac{1}{2 \sigma_{\varepsilon}^{2}}\left(\mathbf{e}^{\prime} \mathbf{e}\right)\right\} .
$$

Obliczenie charakterystyk rozkładów a posteriori, wyrażonych równaniami 5-7, umożliwiło wykorzystanie metod Monte Carlo typu łańcuchów Markowa (MCMC). Dla parametrów $\boldsymbol{\beta}$ i $\sigma_{\varepsilon}^{2}$ zastosowano losowanie Gibbsa, będące jedną z częściej wykorzystywanych metod numerycznych stosowanych w badaniach empirycznych. Polega ono na wielokrotnym generowaniu w sposób sekwencyjny liczb pseudolosowych z przedstawionych rozkładów a posteriori.

W przeciwieństwie do dwóch pierwszych parametrów, rozkład a posteriori parametru $\rho$ nie odzwierciedla żadnego ze znanych rozkładów. W związku z tym, w celu wyznaczenia kolejnych wartości z rozkładu a posteriori parametru $\rho$, zastosowano metodę odwrotnej dystrybuanty (generowanie liczb losowych $\mathrm{z}$ odwracaniem dystrybuanty). W każdej iteracji wyznaczono skumulowany rozkład $\rho$, dokonując numerycznej integracji rozkładu gęstości (por. m.in. Pace i in., 1997, LeSage i in., 2009), a następnie losowano wartość $\rho$.

Zgodnie z metodą MCMC w każdej kolejnej iteracji wykorzystywano wartości parametrów z poprzedniej iteracji, uzyskując tzw. łańcuch Markowa. Stosowany łańcuch Markowa był zbieżny do rozkładu stacjonarnego przy łącznej liczbie iteracji ustalonej na 10 000, przyjmując 5000 jako liczbę cykli spalonych ${ }^{2}$.

\section{ZAŁOŻENIA EKSPERYMENTU SYMULACYJNEGO}

Symulację przeprowadzono oddzielnie dla dwóch procesów przestrzennych, cechujących się autokorelacją przestrzenną i/lub przestrzenną heterogenicznością. Rozpatrzono następujące przypadki:

$$
\begin{aligned}
& \mathbf{Y}=\left(\mathbf{I}_{N}-\rho \mathbf{W}\right)^{-1}\left(\mathbf{X} \boldsymbol{\beta}+\boldsymbol{\varepsilon}+\Delta\left(\mathbf{I}_{J}-\lambda \mathbf{M}\right)^{-1} \boldsymbol{\mu}\right), \\
& \mathbf{Y}=\left(\mathbf{I}_{N}-\rho \mathbf{W}\right)^{-1}(\mathbf{X} \boldsymbol{\beta}+\boldsymbol{\varepsilon}+\boldsymbol{\Delta} \boldsymbol{\mu}), \\
& \boldsymbol{\mu} \sim \mathrm{N}\left(\mathbf{0}, \sigma_{\mu}^{2} \mathbf{I}_{J}\right),
\end{aligned}
$$

gdzie:

$\mathbf{M}$ - standaryzowana wierszami macierz $J \times J$ wag przestrzennych,

$\rho, \lambda$ - parametry interakcji przestrzennych,

$\boldsymbol{\mu}$ - wektor $J \times 1$ efektów losowych,

\footnotetext{
${ }^{2}$ Badanie zbieżności łańcuchów Markowa przeprowadzono w programie R Cran, korzystając z pakietu coda (Plummer i in., 2005).
} 
$J$ - łączna liczba efektów losowych w próbie.

Przez $\Delta$ oznaczono macierz blokowo-diagonalną o wymiarach $N \times J$ następującej postaci:

$$
\boldsymbol{\Delta}=\left[\begin{array}{cccc}
\mathbf{l}_{1} & \mathbf{0} & \cdots & \mathbf{0} \\
\mathbf{0} & \mathbf{l}_{2} & \cdots & \mathbf{0} \\
\cdots & \cdots & \cdots & \cdots \\
\mathbf{0} & \mathbf{0} & \cdots & \mathbf{l}_{J}
\end{array}\right],
$$

gdzie:

$\mathbf{0}$ - wektor $n_{j} \times 1$ zer,

$\mathbf{l}_{j}$ - wektor $n_{j} \times 1$ jedynek,

$n_{j}-$ liczba jednostek przestrzennych w grupie $j$.

Jak wskazuje Szulc (2007, s. 47), procesy przestrzenne stanowią funkcje $Y(s)$ argumentów $s=\left[s_{1}, s_{2}\right] \in R^{2}$. Można zatem przyjąć, że procesy wyrażone równaniami 8-10 są procesami $Y\left(s_{i}\right)$, tj. obserwowanymi na płaszczyźnie, w lokalizacjach przestrzennych $s_{i}=\left[s_{1 \mathrm{i}}, s_{2 i}\right]$, gdzie $i=1,2, \ldots, N$ jest numerem jednostki przestrzennej.

Na potrzeby wyznaczenia elementów $w_{i j}$ macierzy wag przestrzennych W oraz M wygenerowano regularną siatkę punktów (grid) z lokalizacjami przestrzennymi $N=900$ jednostek $^{3}$. Dodatkowo wydzielono $J=100$ jednakowych grup, zawierających po $n_{j}=9$ jednostek przestrzennych. Każdą grupę $j$ traktować można jako wyższy stopień agregacji jednostek $i$. Dla tak wyznaczonych lokalizacji obliczono odległości $d_{i j}$ między każdą parą punktów $i$ oraz $j$, stosując metrykę euklidesową. W przypadku odległości między $J$ grupami w kalkulacji odległości wykorzystano informacje o położeniu centroidu grupy. Dla regularnej siatki punktów lokalizację centroidu grupy $j$ można obliczyć jako $s_{(29+j \times 3) \times q(j / 10-0,1)}$, gdzie $q$ jest częścią całkowitą dzielenia.

W poszczególnych macierzach wag przestrzennych zastosowano następujące funkcje ważenia odległości:

- dla macierzy $\mathbf{W}$ :

$$
\forall i, j \in\{1, \ldots, N\} \wedge i \neq j: w_{i j}=\exp \left(-d_{i j}^{2}\right) \text {, }
$$

- dla macierzy $\mathbf{M}$ :

$$
\begin{aligned}
& \forall i, j, l \in\{1, \ldots, J\}: w_{i j}=1 \Leftrightarrow \forall j \in K N N(i, J), \\
& \forall l \in J-K N N(i, J), d_{i j} \leq d_{i l},
\end{aligned}
$$

\footnotetext{
${ }^{3} \mathrm{~W}$ pracy zrezygnowano $\mathrm{z}$ wprowadzenia warunkowania macierzy $\mathbf{W}$ i $\mathbf{M}$, jak również z analizy ogólniejszych procesów, np. nieskorelowanych przestrzennie.
} 
gdzie: $K N N(i, J)$ jest zbiorem $k=1$ obserwacji pochodzących ze zbioru $J$ grup, będących najbliższym sąsiadem dla $i$.

Tabela 1. Wartości docelowe parametrów

\begin{tabular}{ccccc}
\hline $\begin{array}{c}\text { Warianty dla } \\
\text { procesu 1 }\end{array}$ & $\begin{array}{c}\text { Warianty dla } \\
\text { procesu 2 }\end{array}$ & $\rho$ & $\lambda$ & $\sigma \mu 2$ \\
\hline 1 & 1 & 0,20 & 0,20 & 0,20 \\
2 & & 0,20 & 0,40 & 0,20 \\
3 & & 0,20 & 0,60 & 0,20 \\
4 & 2 & 0,20 & 0,80 & 0,20 \\
& 3 & 0,20 & & 0,40 \\
& 4 & 0,20 & & 0,60 \\
& 5 & 0,20 & & 0,80 \\
5 & 6 & 0,40 & & 0,20 \\
6 & & 0,40 & 0,20 & 0,40 \\
7 & & 0,40 & 0,40 & 0,40 \\
8 & & 0,40 & 0,60 & 0,40 \\
& & 0,40 & 0,80 & 0,40 \\
& 8 & 0,40 & & 0,60 \\
& & 0,40 & & 0,80 \\
9 & 9 & 0,60 & & 0,20 \\
10 & 10 & 0,60 & & 0,40 \\
11 & 11 & 0,60 & 0,20 & 0,60 \\
12 & & 0,60 & 0,40 & 0,60 \\
& & 0,60 & 0,60 & 0,60 \\
& & 0,60 & 0,80 & 0,60 \\
13 & 12 & 0,60 & & 0,80 \\
14 & 13 & 0,80 & & 0,20 \\
16 & 14 & 0,80 & & 0,40 \\
& 15 & 0,80 & & 0,60 \\
& 16 & 0,80 & 0,20 & 0,80 \\
& & 0,80 & 0,40 & 0,80 \\
& & 0,80 & 0,60 & 0,80 \\
& & 0,80 & 0,80 & 0,80 \\
\hline
\end{tabular}

Źródło: opracowanie własne.

Symulację przeprowadzono dla 16 kombinacji wartości parametrów $\rho, \lambda$ i $\sigma_{\mu}^{2}$ (por. tabela 1). Dla procesu wyrażonego równaniem 8 zastosowano kombinację wartości parametrów $\rho, \lambda$ oraz $\sigma_{\mu}{ }^{2} \mathrm{w}$ celu określenia skali błędów ocen parametrów wynikających z różnej siły interakcji przestrzennych na dwóch poziomach agregacji przestrzennej oraz skali przestrzennej heterogeniczności. W przypadku procesu wyrażonego równaniem $9 \mathrm{w}$ poszczególnych wariantach różnicowano wartości parametrów $\rho$ oraz $\sigma_{\mu}{ }^{2}$, podobnie jak w równaniu 8 kontrolując siłę oddziaływań przestrzennych i skalę niejednorodności, przy czym założono brak dodatkowych interakcji na wyższym poziomie agregacji przestrzennej. 
Dla wszystkich procesów przyjęto stałą wartość wariancji składnika losowego $\sigma_{\varepsilon}^{2}=0,2$ oraz wartości parametrów strukturalnych $\boldsymbol{\beta}=[0,3,0,7]$. Liczbę objaśniających procesów przestrzennych ustalono na $K=2$. Wygenerowane zostały niezależnie od siebie, przy czym wartości obu pochodziły z rozkładu normalnego o zerowej wartości średniej i wariancji równej jeden.

Dla każdej kombinacji wartości docelowych parametrów, w poszczególnych procesach, ustalono $R=50$ replikacji. Niewielka, w porównaniu z tradycyjnie przyjmowaną w symulacjach Monte Carlo, liczba replikacji wynikała $\mathrm{z}$ długiego czasu estymacji modelu SAR metodami bayesowskimi ${ }^{4}$. Łącza liczba replikacji dla każdego procesu wynosiła 800.

W badaniu wykorzystano dwie najpowszechniej stosowane miary, pozwalające na ocenę wielkości błędów ocen parametrów i błędów standardowych tychże ocen:

- względny błąd estymatora $\hat{E}$ parametru $E$ :

$$
B(\hat{E})=\frac{\bar{E}-E}{E} \cdot 100 \% \text {, }
$$

gdzie: $\widehat{E}$ - średnia arytmetyczna obliczona z $R$ replikacji na podstawie wartości oczekiwanej rozkładu a posteriori parametru $E$ (por. Domański i in., $2000)^{5}$.

Analogicznie jak Hoogland i in. (1998, s. 329-367) przyjęto maksymalną dopuszczalną wartość błędu $5 \%$.

- wskaźnik pokrycia przedziału z 95\% wiarygodnością:

$$
\begin{aligned}
& C(C I(\hat{E}))=\frac{\sum C I\left(\hat{E}_{r}\right)}{R} \cdot 100 \%, \\
& C I\left(\hat{E}_{r}\right)=\left\{\begin{array}{l}
1 \text { gdy } E \in C I \\
0 \text { gdy } E \notin C I
\end{array}\right.
\end{aligned}
$$

gdzie: CI - 95\% przedział wartości parametru $E$, którego dolną granicę obliczono jako kwantyl rzędu 0,025 rozkładu a posteriori parametru, a górną jako kwantyl rzędu 0,975. W celu stwierdzenia, czy wartości względnego błędu estymatora różnią się w zależności od wartości docelowej parametru, przeprowadzono analizę ANOVA.

\footnotetext{
${ }^{4} \mathrm{~W}$ efekcie skala dokładności oszacowań względnych błędów estymatora (pow. równanie 14) jest niższa od tej, jaką uzyskano by, stosując większą liczbę replikacji.

${ }^{5}$ Rozkłady brzegowe a posteriori wszystkich rozważanych parametrów były symetryczne, jednomodalne. W takim przypadku $95 \%$ przedziały wartości parametrów pokrywają się z przedziałami o najwyższych wartościach funkcji gęstości a posteriori (HPD).
} 


\section{WYNIKI SYMULACJI MONTE CARLO}

Wyniki symulacji zaprezentowano $\mathrm{w}$ podrozdziałach odpowiadających rozważanym procesom przestrzennym. W przypadku estymacji modelu SAR dla procesu opisanego równaniem 9 uzyskane wyniki interpretować można w kontekście efektu pominięcia przestrzennej heterogeniczności (podrozdział 3.1). Wyniki estymacji procesu opisanego równaniem (8) pozwalają określić wpływ pominięcia przestrzennej heterogeniczności oraz obecności dodatkowych interakcji przestrzennych dla wyższego stopnia agregacji (podrozdział 3.2).

\subsection{EFEKT POMINIĘCIA PRZESTRZENNEJ HETEROGENICZNOŚCI}

Oceny parametrów modelu SAR dla procesu z heterogenicznością przestrzenną (wyrażoną losowymi efektami) wskazują, że dla ocen parametrów stojących przy zmiennych objaśniających względny błąd estymatora nie przekracza 5\%. Oznacza to, że zarówno estymator parametru $\beta_{1}$, jak i $\beta_{2}$ jest nieobciążony (por. tabela 2). Pominięta heterogeniczność przestrzenna nie wpłynęła również negatywnie na $95 \%$ bayesowski przedział ufności obu parametrów, o czym świadczą wysokie wartości wskaźnika pokrycia.

Tabela 2. Wpływ pominiętej przestrzennej heterogeniczności na oszacowania parametrów i $95 \%$ obszaru ufności w modelu SAR

\begin{tabular}{ccc}
\hline Parametr & $\begin{array}{c}\text { Względny błąd } \\
\text { estymatora }\end{array}$ & $\begin{array}{c}\text { Wskaźnik } \\
\text { pokrycia 95\% przedziału }\end{array}$ \\
\hline$\beta 1$ & $1 \%$ & $95 \%$ \\
$\beta 2$ & $2 \%$ & $80 \%$ \\
$\rho$ & $36 \%$ & $0 \%$ \\
$\sigma \varepsilon 2$ & $23 \%$ & $0 \%$ \\
\hline
\end{tabular}

Obliczono na podstawie $R=800$.

Źródło: obliczenia własne w R Cran.

Sytuacja ulega zmianie w przypadku oceny parametru interakcji przestrzennych $\rho$ oraz wariancji składnika losowego $\sigma_{\varepsilon}^{2}$. Względny błąd estymatora dla obu przekracza znacząco wartość $5 \%$, potwierdzając znaczące przeszacowanie. Wyznaczone dla obu parametrów 95\% przedziały wiarygodności nie zawierają rzeczywistej wartości parametrów, co znajduje odzwierciedlenie w zerowych wartościach wskaźników pokrycia.

Uzyskane wyniki dają jedynie ogólną informację dotyczącą skutków pominięcia heterogeniczności przestrzennej w modelu SAR. W celu określenia związku między skalą niejednorodności przestrzennej (wartość $\sigma_{\mu}{ }^{2}$ ) a wartościami błędów estymatora wykonano analizę ANOVA (tabela 3). 
Wynika z niej, że wartość parametru $\rho$ różnicuje wielkość błędu estymatora parametru $\beta_{1}, \beta_{2}$ oraz $\rho$, przy czym dla $\beta_{1}$ i $\beta_{2}$ nie stwierdzono obciążenia. W przypadku $\rho$ zauważono, że im większa wartość parametru, tym mniejszy względny błąd estymatora. Dla wartości $\rho=0,20$ względny błąd wyniósł aż $53 \%$, dla $\rho=0,40$ było to $43 \%$. Wartości $\rho=0,60$ oraz $\rho=0,80$ odznaczały się zaś najmniejszym względnym błędem estymatora, który wyniósł odpowiednio 32\% i 18\%. Wynik ten sugeruje, że dla procesów silnie skorelowanych przestrzennie negatywny efekt pominięcia heterogeniczności w modelu SAR, wyrażony wielkością błędu estymatora, będzie nieco mniejszy, chociaż uzyskana ocena parametru $\rho$ wciąż będzie przeszacowana.

Tabela 3. Wpływ wartości $\rho$ i $\sigma_{\mu}^{2}$ na oceny parametrów modelu SAR - wyniki analizy ANOVA

\begin{tabular}{ccc}
\hline Parametr & $\rho$ & $\sigma \mu 2$ \\
\hline$\beta 1$ & 0,00 & 0,48 \\
$\beta 2$ & 0,00 & 0,20 \\
$\rho$ & 0,00 & 0,00 \\
$\sigma \varepsilon 2$ & 0,36 & 0,00 \\
\hline
\end{tabular}

Obliczono na podstawie $R=200$ (wariant parametru). W tabeli podano wartości p-value.

Źródło: obliczenia własne w R Cran.

Zauważono również, że skala heterogeniczności przestrzennej, rozumiana jako wartość wariancji efektów losowych $\left(\sigma_{\mu}^{2}\right)$, w sposób istotny statystycznie zróżnicuje względny błąd estymatora parametru $\rho$ oraz $\sigma_{\varepsilon}^{2}$. W szczególności w przypadku wariancji składnika losowego wzrost heterogeniczności przestrzennej powoduje wzrost wartości względnego błędu estymatora. Dla $\sigma_{\mu}{ }^{2}=0,20$ względny błąd estymatora wariancji składnika losowego wyniósł zaledwie $11 \%$, dla $\sigma_{\mu}{ }^{2}=0,40$ wartość błędu wyniosła już $19 \%$, a przy $\sigma_{\mu}{ }^{2}=0,60$ względny błąd estymatora $\sigma_{\varepsilon}{ }^{2}=27 \%$. Dla procesu o najsilniejszej skali przestrzennej heterogeniczności $(0,80)$ względny błąd estymatora wariancji składnika losowego w modelu SAR wyniósł 33\%.

\subsection{EFEKT POMINIĘCIA SKORELOWANYCH PRZESTRZENNIE EFEKTÓW LOSOWYCH}

W dalszej kolejności wzięto pod uwagę proces przestrzenny, w przypadku którego wprowadzono zarówno heterogeniczność przestrzenną, jak i dodatkowe interakcje przestrzenne $\mathrm{w}$ postaci skorelowanych przestrzennie efektów losowych. Uzyskane wyniki (tabela 4) wskazują, że podobnie jak w przypadku pominięcia heterogeniczności, estymator parametru $\beta_{1}$ i $\beta_{2}$ pozostaje nieobciążony. Względny błąd estymatora $\mathrm{w}$ obu przypadkach jest nieznaczny, co wskazuje na niedoszacowanie o 1 i $2 \%$. Analogicznie, 
wskaźniki pokrycia 95\% przedziału wiarygodności są wysokie (93\% i 81\%), co potwierdza brak negatywnego wpływu pomiętych efektów przestrzennych na oszacowania błędów ocen parametrów.

Tabela 4. Wpływ pominięcia skorelowanych przestrzennie efektów losowych na oszacowania parametrów i 95\% przedziału wiarygodności w modelu SAR

\begin{tabular}{ccc}
\hline Parametr & $\begin{array}{c}\text { Względny błąd } \\
\text { estymatora }\end{array}$ & $\begin{array}{c}\text { Wskaźnik } \\
\text { pokrycia 95\% przedziału }\end{array}$ \\
\hline$\beta 1$ & $-1 \%$ & $93 \%$ \\
$\beta 2$ & $-2 \%$ & $81 \%$ \\
$\rho$ & $38 \%$ & $0 \%$ \\
$\sigma \varepsilon 2$ & $28 \%$ & $0 \%$ \\
\hline
\end{tabular}

Obliczono na podstawie $R=800$.

Źródło: obliczenia własne w R Cran.

Sytuacja ta ulega zmianie dla ocen parametru interakcji przestrzennych $\rho$ oraz wariancji składnika losowego. Względny błąd estymatora parametru $\rho$ w sytuacji, gdy w modelu SAR nie uwzględniono skorelowanych przestrzennie efektów losowych, wyniósł $38 \%$. W porównaniu do modelu, w którym pominięto nieskorelowane przestrzennie efekty losowe, jest to wynik porównywalny. Sugeruje to, że uwzględnienie efektów losowych ma dominujące znaczenie dla uzyskania prawidłowej oceny parametru $\rho$, a dodatkowe interakcje przestrzenne efektów losowych jedynie nieznacznie zwiększają przeszacowanie wartości parametru.

Inaczej jest w przypadku oszacowań wariancji składnika losowego. Podobnie jak w modelu SAR z pominiętymi efektami losowymi, wielkość względnego błędu estymatora przekracza 5\%, potwierdzając przeszacowanie wariancji składnika losowego w sytuacji pominięcia skorelowanych przestrzennie efektów losowych. Jednocześnie wartość błędu jest o 5 p.p. wyższa od tej, którą odnotowano w przypadku pominięcia nieskorelowanych przestrzennie efektów losowych. Fakt ten świadczyć może o tym, że pominięcie skorelowanych efektów losowych znajduje odzwierciedlenie w podwyższeniu względnego błędu estymatora wariancji składnika losowego. Co więcej, można się spodziewać, że uzyskane na podstawie modelu SAR reszty będą skorelowane przestrzennie, przy czym struktura zależności będzie wyrażona w postaci interakcji grupowych, analogicznych do tych, które zawarto w macierzy $\mathbf{M}$.

W celu określenia, czy poziom skorelowania efektów losowych (wyrażony parametrem interakcji przestrzennych $\lambda$ ) oraz skala przestrzennej heterogeniczności (wyrażona wariancją efektów losowych $\sigma_{\mu}{ }^{2}$ ) różnicują w spo- 
sób istotny statystycznie wartości względnych błędów estymatora parametrów modelu SAR, przeprowadzono analizę ANOVA (tabela 5).

Tabela 5. Wpływ wartości $\lambda$ i $\sigma_{\mu}{ }^{2}$ na oceny parametrów modelu SAR - wyniki analizy ANOVA

\begin{tabular}{ccc}
\hline Parametr & $\lambda$ & $\sigma_{\mu}{ }^{2}$ \\
\hline$\beta_{1}$ & 0,52 & 0,28 \\
$\beta_{2}$ & 1,00 & 0,00 \\
$\rho$ & 0,00 & 0,00 \\
$\sigma_{\varepsilon}{ }^{2}$ & 0,00 & 0,00 \\
\hline
\end{tabular}

Obliczono na podstawie $R=200$ (wariant parametru). W tabeli podano wartości p-value.

Źródło: obliczenia własne w R Cran.

Uzyskane wyniki wskazują, że zarówno wartość $\lambda$, jak i $\sigma_{\mu}^{2}$ różnicują skalę przeszacowania ocen parametrów $\rho$ i $\sigma_{\varepsilon}^{2}$. Względny błąd estymatora parametru $\rho$ wahał się od $34 \%$ dla $\lambda=0,20$ do $43 \%$ dla $\lambda=0,80$, wykazując stopniowy wzrost wraz ze wzrostem wartości parametru $\lambda$. Analogiczną sytuację odnotowano w przypadku względnego błędu estymatora wariancji składnika losowego, uzyskując kolejno: dla $\lambda=0,20$ i $\lambda=0,40$ wartość błędu $\sigma_{\varepsilon}{ }^{2}=24 \%$, dla $\lambda=0,60$ błąd $\sigma_{\varepsilon}{ }^{2}=26 \%$, a dla $\lambda=0,80$ błąd $\sigma_{\varepsilon}{ }^{2}=38 \%$. Oznacza to, że im bardziej efekty losowe są skorelowane przestrzennie, tym większe jest przeszacowanie parametru interakcji przestrzennych i wariancji składnika losowego w modelu SAR.

Podobne wnioski można sformułować, analizując wpływ wartości $\sigma_{\mu}{ }^{2}$ na oceny ww. parametrów. W szczególności wzrost skali heterogeniczności przestrzennej znajduje swoje odzwierciedlenie w coraz większym przeszacowaniu wariancji składnika losowego (rysunek 1). Dla każdej z czterech wartości wariancji efektów losowych wartość względnego błędu estymatora parametru $\sigma_{\varepsilon}{ }^{2}$ była wyższa dla procesu cechującego się skorelowaniem efektów losowych, niż w przypadku efektów losowych nieskorelowanych przestrzennie. Warto zauważyć, że dla procesu o najwyższej skali heterogeniczności przestrzennej względny błąd estymatora różni się aż o 13 p. p. w zależności od tego, czy efekty losowe są skorelowane przestrzennie, czy też są niezależne. 


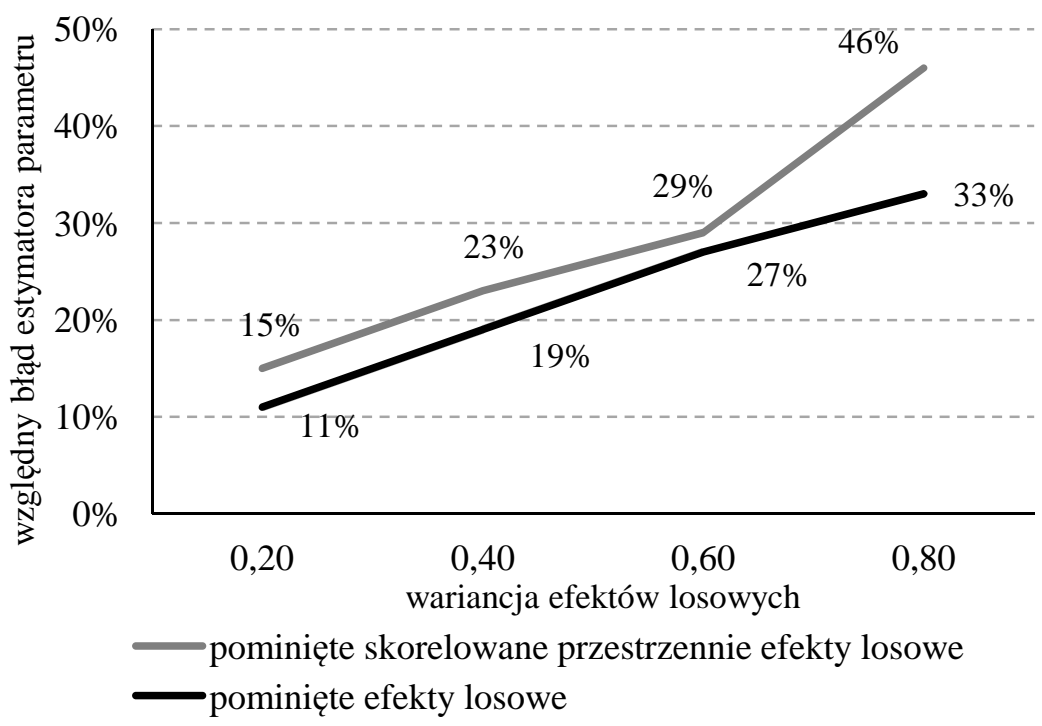

Rysunek 1. Względny błąd estymatora parametru $\sigma_{\varepsilon}^{2} \mathrm{~W}$ zależności od wartości $\sigma_{\mu}{ }^{2}$

Źródło: obliczenia własne.

Uzyskane wyniki wskazują, że pominięcie skorelowanych przestrzennie lub niezależnych od siebie efektów losowych wpływa negatywnie wyłącznie na oceny parametrów interakcji przestrzennych oraz wariancji składnika losowego w modelu SAR. Wielkość przeszacowania parametru interakcji przestrzennych $\rho$ jest porównywalna dla obu przypadków i wynika ze skali pominiętej heterogeniczności przestrzennej $\left(\sigma_{\mu}{ }^{2}\right)$. W przypadku oszacowań wariancji składnika losowego zauważyć można, że wielkość przeszacowania jest wyższa w sytuacji, gdy pominięte efekty losowe są skorelowane przestrzennie.

\section{WNIOSKI}

Uzyskane wyniki wskazują, że pominięcie heterogeniczności przestrzennej (w postaci efektów losowych), jak również pominięcie heterogeniczności i dodatkowych zależności przestrzennych (rozumianych jako obecność skorelowanych przestrzennie efektów losowych), wpływa negatywnie na błąd estymatora parametrów interakcji przestrzennych, który każdorazowo jest przeszacowany w modelu SAR. Przeszacowaniu, wskutek pominięcia dodatkowych charakterystyk procesu przestrzennego, ulega również wariancja składnika losowego. Co ważne, nieuwzględnienie efektów losowych (skore- 
lowanych przestrzennie bądź niezależnych) nie wpływa na oszacowania parametrów zmiennych objaśniających. Dla tych ostatnich względny błąd estymatora jest wciąż niewielki (poniżej 5\%), a wskaźnik pokrycia 95\% przedziału wiarygodności wysoki.

Różnice między wartością względnych błędów estymatora parametru interakcji przestrzennych $\mathrm{w}$ modelu SAR w przypadku pominięcia niezależnych i skorelowanych przestrzennie efektów losowych są nieznaczne (2 p.p.). Oznacza to, że o ile sam fakt pominięcia efektów losowych powoduje przeszacowanie parametru interakcji przestrzennych, o tyle to, czy efekty losowe pozostają niezależne, czy też cechują się określoną strukturą relacji, ma znaczenie drugorzędne w przypadku oszacowań parametru interakcji przestrzennych.

Inaczej jest w przypadku oszacowań wariancji składnika losowego. W przypadku procesu cechującego się niezależnymi efektami losowymi względny błąd estymatora wariancji składnika losowego jest mniejszy, niż gdy efekty losowe pozostają ze sobą skorelowane przestrzennie (por. rysunek 1). Co więcej, w przypadku silnego zróżnicowania efektów losowych (wyższa wartość $\sigma_{\mu}{ }^{2}$ ) fakt skorelowania tychże efektów powoduje znaczący wzrost względnego błędu estymatora wariancji składnika losowego, co nie jest zauważalne w przypadku nieskorelowanych efektów losowych.

Dla obu procesów przestrzennych zauważono, iż skala przeszacowania parametru interakcji przestrzennych, jak również wariancji składnika losowego wynika ze skali niejednorodności przestrzennej zjawiska oraz siły interakcji przestrzennych. Im bardziej niejednorodny proces (wyższa wartość $\sigma_{\mu}^{2}$ ), tym wyższy względny błąd estymatora wariancji składnika losowego. Analogicznie, im bardziej efekty losowe są ze sobą przestrzennie skorelowane, tym wyższy względny błąd estymatora parametru interakcji przestrzennych i wariancji składnika losowego w modelu SAR.

\section{PODSUMOWANIE}

Niniejsze badanie miało na celu wskazanie skutków błędnej specyfikacji modelu SAR, rozumianej jako pominięcie faktu występowania dodatkowych charakterystyk procesu przestrzennego. Skoncentrowano się na dwóch procesach - odznaczających się występowaniem niezależnych i skorelowanych przestrzennie efektów losowych. W celu określenia skutków pominięcia wspomnianych efektów, w modelu SAR, skorzystano z symulacji Monte Carlo.

Wyniki symulacji wskazują na wrażliwość oszacowań parametru interakcji przestrzennych oraz wariancji składnika losowego - w modelu SAR na pominięcie dodatkowych charakterystyk procesu przestrzennego. Oba są 
przeszacowane w przypadku pominięcia niezależnych bądź skorelowanych przestrzennie efektów losowych. W przypadku parametru interakcji przestrzennych względny błąd estymatora jest porównywalny, gdy pominięte efekty losowe są skorelowane przestrzennie bądź niezależne. Skala przeszacowania wariancji składnika losowego różni się jednak dla obu procesów i jest wyższa w sytuacji, gdy pominięte efekty losowe są skorelowane przestrzennie.

\section{LITERATURA}

Anselin L. (1988), Spatial Econometrics: Methods and Models, Vol. 4. Springer.

Anselin L., Griffith D. A. (1988), Do spatial effects really matter in regression analysis?, „Papers in Regional Science”, 65(1), 11-34.

Domański Cz., Pruska K. (2000), Nieklasyczne metody statystyczne, Polskie Wydawnictwo Ekonomiczne, Warszawa.

Goldstein H. (2011), Multilevel Statistical Models, John Wiley \& Sons.

Hoogland J., Boomsma A. (1998) Robustness studies in covariance structure modeling: An overview and a meta-analysis, ,Sociological Methods and Research”, 26(3), 329-367.

Lee L. F. (2002), Consistency and efficiency of least squares estimation for mixed regressive, spatial autoregressive models, „Econometric Theory”, 18(02), 252-277.

Lee L. F. (2007), GMM and 2SLS estimation of mixed regressive, spatial autoregressive models, ,Journal of Econometrics”, 137(2), 489-514.

LeSage J. (1997), Bayesian estimation of spatial autoregressive models, „International Regional Science Review", 20(1-2), 113-129.

LeSage J., Pace R. K. (2009), Introduction to Spatial Econometrics, CRC Press.

Liu A., Folmer H., Oud J. H. (2014), Estimation of autoregressive models with two types of weak spatial dependence by means of the W-based and the latent variables approach: evidence from Monte Carlo simulations, „Environment and Planning”, A, 46(1), $186-202$.

Moerbeek M. (2004), The consequence of ignoring a level of nesting in multilevel analysis, „Multivariate Behavioral Research”, 39.1, 129-149.

Osiewalski J. (2001), Ekonometria bayesowska w zastosowaniach, Wyd. AE w Krakowie, Kraków.

Pace R. K., Barry R. (1997), Quick computation of spatial autoregressive estimators, "Geographical analysis", 29.3, 232-247.

Plummer M., Best N., Cowles K., Vines K. (2005), CODA: output analysis and diagnostics for $M C M C, \mathrm{R}$ package version 0. 9-2.

Suchecki B. (red.), (2010), Ekonometria przestrzenna, Wydawnictwo C.H.Beck, Warszawa.

Szulc E. (2007), Ekonometryczna analiza wielowymiarowych procesów gospodarczych, Wydawnictwo Uniwersytetu Mikołaja Kopernika, Toruń.

Van den Noortgate W., Opdenakker M. C., Onghena P. (2005), The effects of ignoring a level in multilevel analysis, „School Effectiveness and School Improvement”, 16(3), 281-303. 


\title{
MISSPECIFICATION OF SPATIAL EFFECTS IN THE BAYESIAN SPATIAL AUTOREGRESSIVE MODEL. THE RESULTS FROM THE MONTE CARLO SIMULATION
}

\begin{abstract}
A b s t r a ct: The aim of this paper is to analyze the impact of the SAR model misspecification. We concentrate on the effect of ignoring random effects (both independent and spatially correlated) in the SAR model. The results from the Monte Carlo simulation suggests the overestimation of the spatial parameter and error variance if the random effects are omitted in the SAR model.
\end{abstract}

K e y w o r d s: spatial autoregressive model, Bayesian MCMC, Monte Carlo simulation. 